DOI 10.18551/rjoas.2021-09.04

\title{
THE EFFECT OF FISCAL DECENTRALIZATION ON FINANCIAL PERFORMANCE AND ITS IMPLICATIONS ON VILLAGE FINANCIAL MANAGEMENT ACCOUNTABILITY
}

\author{
Amin M.* \\ Master's Program of Accounting, Faculty of Business and Economics, University of Mataram, \\ Indonesia
}

\author{
Akram, Irwan M. \\ Faculty of Business and Economics, University of Mataram, Indonesia
}

*E-mail: aminlombok77@gmail.com

\begin{abstract}
This study aims to analyze village original income, transfer funds, and other funds on village financial performance and village financial management accountability. The sampling technique used is purposive sampling, with a population of 127 villages in Central Lombok district. The sample in this study amounted to 20 villages in the category of developed villages. The variables used in this study are village original income, transfer funds, other funds, financial performance, and accountability. The results showed that village original income had a positive and significant effect on financial performance and accountability. Transfer funds have a positive and significant effect on financial performance. For other fund variables, it has no effect on financial performance and accountability. Financial performance variable has no effect on accountability.
\end{abstract}

\section{KEY WORDS}

Original village income, transfer funds, other funds, financial performance, accountability.

Indonesia is a unitary state consisting of 34 provinces, 514 cities/districts, 7,201 subdistricts and 83,436 villages/kelurahan, each of which has its own local government (Permendagri Number 137 of 2017 concerning Codes and Data for Government Administration Areas). The village is a legal community unit that has territorial boundaries that are authorized to regulate and manage the interests of the community based on local origins and customs that are recognized and respected in the system of the Government of the Unitary State of the Republic of Indonesia ("Village Financial System," 2018).

As a form of state recognition of the village, especially in the context of clarifying the functions, authorities, and strengthening the position of the village and village communities as development subjects, a policy and regulations regarding the village are needed. Therefore, Law no. 6 of 2014 concerning Villages accompanied by PP No. 43 concerning the Implementing Regulations and PP No. 60 of 2014 concerning Village Funds. With this regulation, it can provide new hope for more optimal village development.

Fiscal decentralization is currently a major concern and a phenomenon for countries in the world, both in developed and developing countries, including Indonesia. Experience in developed countries, as well as many developing countries, is turning towards (fiscal) decentralization as an effort to escape from various problems of government ineffectiveness and inefficiency, as well as macroeconomic instability (Bahl and Linn, 1992). Not much different from the global trend, decentralization has become a discourse that continues to roll in its various implementations in Indonesia.

Decentralization is a tool to achieve one of the goals of the state, namely primarily providing better public services and creating a more democratic public decision-making process. Decentralization is realized with the delegation of authority to local governments and the transfer of funds from the government. The impetus for decentralization in Indonesia is motivated by several factors, including: the decline in economic development in the face of global globalization, the increasing demands for changes in the level of public services, and 
the increasingly obvious indications of disintegration due to the failure of the centralized system in the delivery of public services.

Efforts to increase regional and village fiscal capacity are actually not only concerned with increasing PAD or PADes. Increasing fiscal capacity is basically optimizing regional and village revenue sources. Therefore, there is no need to create a dichotomy between Regional Original Income and Village Original Income with Balancing Funds. However, it should also be understood that increasing fiscal capacity does not mean a large budget. Budgets that are made in large numbers but are not managed properly (do not meet the value for money principle) will actually cause problems, such as budget leakage. The Village Fund Allocation (ADD) is part of the balancing fund received by the district/city regional government to allocate it to the APBD every fiscal year at least $10 \%$ after deducting the Special Allocation Fund (DAK). The procedure for allocating ADD is regulated in a regent/mayor regulation.

In relation to the proportion of regional revenues, it can be seen that the regional and village financial systems are very centralized, so that regional financial conditions are highly dependent on the Central Government. Furthermore, Abdullah (2000:47) states that the low PAD of a region is not caused by structurally poor regions or does not have potential financial sources, but is caused by the policies of the Central Government. So far, potential financial sources are controlled by the Central Government, it is hoped that in the future the role of PAD and PADes can shift the role of the Balancing Fund, so that dependence on the Central Government can be reduced.

The Village Fund allocation system is calculated based on the principles of equity and justice, specifically in the Province of West Nusa Tenggara per village an average of Rp720,442. The calculation formulation is then realized by the distribution based on the Basic Allocation (AD) of 90 percent as an element of equity, and the distribution based on the formula (Allocation Formula) which is realized by 10 percent by taking into account the population (weight 25\%), area area (weight 10\%), the poverty rate (weight $35 \%$ ), and the level of geographical difficulty of the village (weight $30 \%$ ) as elements of justice.

Table 1 - Allocation of Village Funds by District for Fiscal Year 2020 West Nusa Tenggara Province (In Thousands)

\begin{tabular}{|l|l|l|l|l|l|}
\hline No & Area name & Number of Villages & Basic Allocation & Allocation Formula & Amount \\
\hline 1 & 2 & 3 & 4 & 5 & 6 \\
\hline 1 & Bima District & 191 & 126.595 .946 & 52.676 .538 & 179.272 .484 \\
\hline 2 & Dompu District & 72 & 47.722 .032 & 25.173 .173 & 72.895 .205 \\
\hline 3 & Lombok Barat District & 119 & 78.873 .914 & 80.756 .638 & 159.630 .552 \\
\hline 4 & Lombok Tengah District & 127 & 84.176 .362 & 122.799 .981 & 206.976 .343 \\
\hline 5 & Lombok Timur District & 239 & 158.410 .634 & 153.606 .990 & 312.017 .624 \\
\hline 6 & Sumbawa District & 157 & 104.060 .542 & 40.693 .159 & 144.753 .701 \\
\hline 7 & Sumbawa Barat District & 57 & 37.779 .942 & 23.745 .807 & 61.525 .749 \\
\hline 8 & Lombok Utara District & 33 & 21.872 .598 & 48.632 .395 & 70.504 .993 \\
\hline
\end{tabular}

Source: $h t t p: / / b p m p d . n t b p r o v . g o . i d$

Furthermore, to be able to maximize its potential, there are two principles used by the village, namely the principle of recognition and the principle of subsidiarity. The recognition principle is a principle that provides opportunities for the village to become a self-governing economy. Villages are given inherent rights of origin and indigenous communities are respected and recognized. This recognition of diversity validates that Villages have different potentials. In addition to the recognition principle, there is the principle of subsidiarity. The principle of subsidiarity means that the village has the ability to take care of itself as long as it is still on a village scale as long as the village is willing and able. The "willing" benchmark is the Village meeting that produces the steps in the RPJMDes and the "able" benchmark is the ability of human resources in the Village to carry out these steps.

In the following table, it can be seen that the sources of village income in Central Lombok Regency in 2016-2019 are as follows: 
Table 2 - Types and Sources of Village Income in Central Lombok Regency (Thousands of Rupiah) for the 2016-2020 Period

\begin{tabular}{|l|l|l|l|l|l|}
\hline \multirow{2}{*}{ Description } & \multicolumn{5}{l|}{ Year } \\
\cline { 2 - 6 } & 2016 & 2017 & 2018 & 2019 & 2020 \\
\hline Village original income & 9.192 .220 & 1.636 .098 & 1.564 .543 & 1.417 .711 & 2.948 .322 \\
\hline Transfer income & 206.881 .666 & 241.372 .330 & 275.965 .087 & 322.918 .698 & 343.092 .615 \\
\hline Other legitimate income & 263.333 & 224.000 & 352.333 & 2.036 .111 & 249.767 \\
\hline
\end{tabular}

Source: Central Lombok Statistics Agency, 2020.

From the aspect of village spending both for financing the fields of village government, development, coaching, and community empowerment since the implementation of village autonomy as stated in Law No. 6 of 2014 concerning Villages, it shows an increase in village spending. For village spending in Central Lombok Regency from 2016-2020, it showed an increase as seen in the following table.

Table 3 - Types of Village Expenditures in Central Lombok Regency (Thousands of Rupiah) for the 2016-2020 Period

\begin{tabular}{|c|c|c|c|c|c|}
\hline \multirow[t]{2}{*}{ Description } & \multicolumn{5}{|l|}{ Year } \\
\hline & 2016 & 2017 & 2018 & 2019 & 2020 \\
\hline Village Government Sector & 103.993 .664 & 87.260 .104 & 91.635 .423 & 101.818 .88 & 134.261 .818 \\
\hline Development Sector & 102.437 .752 & 122.469 .199 & 114.455 .482 & 150.016 .738 & 93.410 .815 \\
\hline Development Field & 10.485 .076 & 15.082 .019 & 17.411 .144 & 25.142 .923 & 16.745 .040 \\
\hline Empowerment Bidang & 66.985 & 13.516 .036 & 42.639 .484 & 36.181 .600 & 8.415 .057 \\
\hline
\end{tabular}

Source: Central Lombok Statistics Agency, 2020.

The table above shows an increase in village spending where in its management the village government is required to have an aspect of good governance, one of the pillars of which is accountability. Accountability is meant here is accountability for village financial management both in the fields of government, development, coaching, and empowerment, all of which are in order to fulfill the welfare of the village community, along with the implementation of autonomy and village financial management which is given quite broadly to the village in other aspects of the use of village finances. The expenditures require transparency and accountability as a form of financial management commitment as outlined in the RPJMDes and APBDes and must be disseminated to the village community.

In the implementation of these expenditures in accordance with the principles of transparency and accountability in financial management, the village government is required to make an expenditure report or village financial report.

\section{METHODS OF RESEARCH}

This research is an associative research with a quantitative approach. Associative research is research that aims to determine the relationship between two or more variables (Sugiyono, 2013: 236). While quantitative research is research that emphasizes theory testing through measuring research variables with numbers and figures. perform data analysis with statistical procedures (Indriantoro and Supomo, 2014: 12).

In this case, the researcher uses the financial performance and accountability of village financial management as the dependent variable (the variable that is affected), while the fiscal decentralization of village finance as the independent variable (the variable that affects).

According to Sugiyono $(2012: 61)$ the sample is part of the population. The samples in this study were all villages in Central Lombok Regency for the 2016-2020 period. The number of samples in this study were 12 villages with the Advanced Village category. Village sampling method with purposive sampling technique, namely the selection of sample members with certain criteria. 
The sample criteria used in this study are based on the developing village index (IDM) according to the Minister of Village Regulation number 2 of 2016 with the category of developed villages, with the following criteria:

1. Has the potential of social, economic and ecological resources;

2. Have the ability to manage to improve the welfare of rural communities;

3. Have the quality of human life and be able to overcome poverty;

4. Have a complete and supportive village government administration.

Based on the above criteria, there are 20 Advanced Villages spread over 12 subdistricts in Central Lombok Regency which will be used as research samples.

Statistical analysis used in this study is a structural model with Partial Least Square (PLS) analysis using SmartPLS 3.0. PLS is a variant-based structural equation analysis (SEM) that can simultaneously test the model measurement model as well as test the structural model (Abdillah and Jogiyanto, 2015:164). Furthermore, Wold in Ghozali and Latan (201526) explains Partial Least Squares is a powerful analytical method and is often referred to as soft modeling because it eliminates OLS (Ordinary Least Squares) regression assumptions, such as the data must be normally distributed multivariately and there are no problems. multicollinearity between exogenous variables.

$$
\mathrm{KKD} 1+\mathrm{APKDes} 2=1 \mathrm{PADes}+2 \mathrm{DTrs}+3 \mathrm{DLL}+\zeta
$$

Where:

$\lambda=$ lambda, coefficient of measurement model;

$\delta=$ delta, measurement model error for latent variable $X$;

$\varepsilon=$ epsilon, measurement model error for latent variable $Y$;

$Y=$ gamma, coefficient of influence of exogenous variables on endogenous variables

$\zeta=$ zeta, structural model error.

\section{RESULTS AND DISCUSSION}

The village is a legal community unit that has the authority to regulate and manage the interests of the local community based on local origins and customs that are recognized in the national government system and are located in the district area. The result of this combination is a form or appearance on earth caused by physiographic, social, economic, political and cultural elements that interact with each other between these elements and also in relation to other areas. Central Lombok regency government has 127 villages. The subjects in this study were developed villages in Central Lombok Regency.

The data used is secondary data obtained from the official website of the Ministry of Villages, the village information system. These data include data on village original income reports, village funds, other legitimate income and also those sourced from the APBDes for the 2017-2020 period.

Convergent validity relates to the principle that the measurer (manifest variable) of a construct should be highly correlated. This test is seen from the loading factor value for each construct indicator. The loading factor range of 0.5 to 0.6 is considered sufficient.

The results of the analysis show that the loading factor value of the DLL2 and DLL3 indicators on the construct of other funds has a value greater than 0.6 , namely 0.885 and 0.673. This means that DLL2 and DLL3 indicators can measure the construct of financial performance in this study. On the other hand, the loading factor value of the DLL1 indicator does not meet the requirements for construct validity of other funds because it has a value less than 0.6, which is 0.415 . This indicates that the DLL1 indicator is not correlated with other fund constructs so that this indicator is dropped from the model. Likewise, the APK1 indicator has a value of 0.502 which is smaller than 0.6 so that it has no correlation with the village financial accountability construct. The results of the re-estimate model after removing the DLL1 and APK1 indicators can be seen in the following figure: 


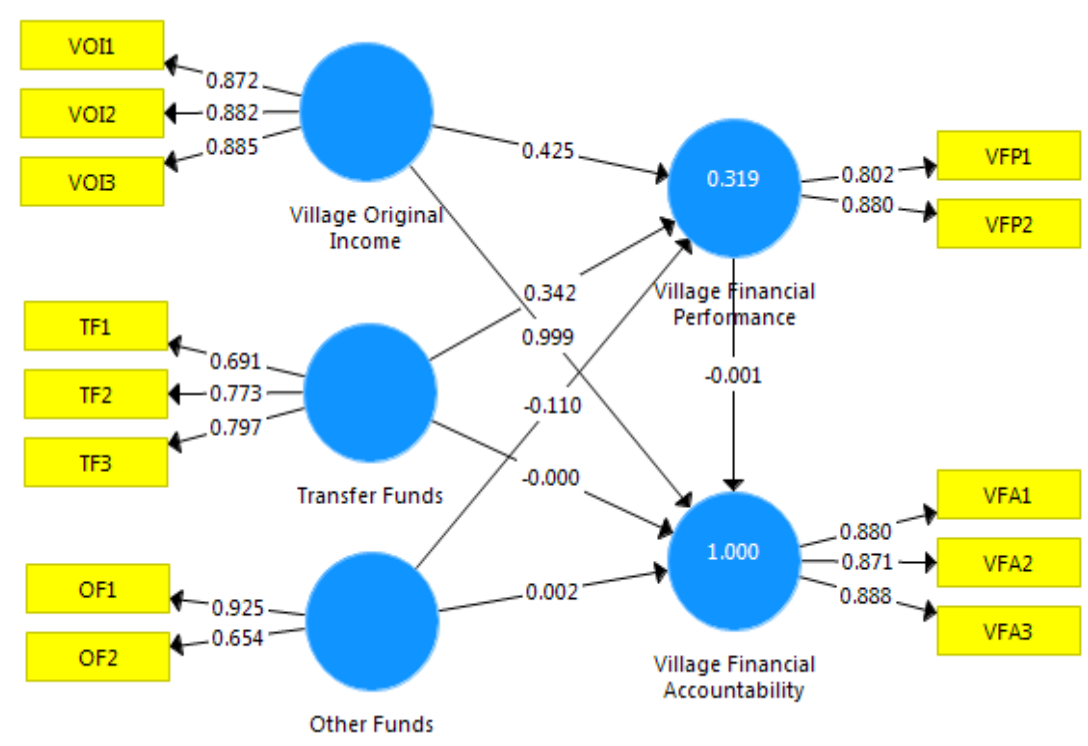

Figure 1 - Results of Re-estimate Model

The results of the re-estimate model after removing the DLL1 indicator make the loading factor values of the OF1 and OF2 indicators 0.925 and 0.654 , respectively. The indicators forming the construct of other funds have met convergent validity because the loading factor value is already above 0.6 , while the APK1 indicator makes the loading factor value of the VFA1, VFA2 and VFA3 indicators $0.880,0.871$ and 0.888 The loading factor value is also supported by the Average value. Variance Extracted (AVE) greater than 0.5.

Table 4 - Results of Path Coefficients Analysis (Path Coefficients)

\begin{tabular}{llll}
\hline Variable & OriginalSample & T Statistics & P Values \\
\hline OF $>$ VFA & 0,024 & 0,378 & 0,706 \\
OF > VFP & $-0,172$ & 1,159 & 0,247 \\
TF > VFA & 0,021 & 0,959 & 0,338 \\
TF > VFP & 0,325 & 3,194 & 0,001 \\
VFP > VFA & 0,035 & 0,701 & 0,483 \\
VOI > VFA & 0,928 & 15,229 & 0,000 \\
VOI > VFP & 0,477 & 4,519 & 0,000 \\
\hline
\end{tabular}

Source: Processed Data, 2021.

The first hypothesis states that the greater the village's original income, the better the accountability of village financial management. Table 4 shows that the t-statistic value for the effect of village original income on village financial management accountability is 4.519 . This value is greater than the value of $t$ table at a significance level of 5 percent, namely 1.99 , so it can be concluded that the hypothesis is accepted. The $P$ value for the effect of village original income on village financial management accountability is 0.000 smaller than the alpha value of 0.05 . This means that the relationship between village original income and village financial management accountability is significant, so the hypothesis is accepted. The coefficient value of the original village income parameter on the accountability of village financial management is 0.477 with a positive direction. This means that the greater the original village income will increase the accountability of village financial management. The village government in Central Lombok Regency also focuses on increasing the village's original income, the higher PADES is a form of the village's ability to manage its own finances, and reflects good performance in financial management.

The second hypothesis states that the greater the village's original income, the better the village's financial performance. Table 4 shows that the t-statistic value for the effect of village original income on village financial performance is 15.229 . This value is greater than the value of t table at a significance level of 5 percent, namely 1.99 , so it can be concluded 
that the hypothesis is accepted. The $P$ value for the effect of village original income on village financial performance is 0.000 smaller than the alpha value of 0.05 . This means that the relationship between village original income and village financial performance is significant, so the hypothesis is accepted. The coefficient value of the original village income parameter on the accountability of village financial management is 0.928 with a positive direction. This means that the greater the village's original income, the better the village's financial performance. Transfer funds sourced from the central government received by the village government are used to finance village needs and develop human resources so that although the transfer funds received by the village government do not guarantee better village financial performance, the greater the transfer funds received from the central government will create independence. The village is increasingly difficult because the village only relies on transfer funds for the needs of the village government.

The third hypothesis states that the larger the transfer funds will not lead to an increase in village financial management accountability. Table 4 shows that the t-statistic value for the effect of transfer funds on village financial management accountability is 0.959 . This value is smaller than the value of $t$ table at a significance level of 5 percent, namely 1.99 , so it can be concluded that the hypothesis is rejected. The $\mathrm{P}$ value for the effect of transfer funds on village financial management accountability is 0.338 greater than the alpha value of 0.05 . This means that the relationship between transfer funds and accountability of village financial management is not significant, so the hypothesis is rejected. The coefficient value of the transfer fund parameter on village financial management accountability is 0.021 with a positive direction. This means that the transfer funds do not have an impact on the accountability of village financial management.

This research is supported by Annisa Riska's research (2019) with the title The Effect of Village Fund Allocation and Village Original Income on Village Expenditures. The results showed that multiple linear regression analysis provided evidence that the allocation of village funds had a significant positive effect on village expenditures, while the other independent variable, namely village original income, had no significant and negative effect on village expenditures. Allocation of village funds is the dominant variable affecting village spending.

The fourth hypothesis states that the greater the transfer funds, the better the village financial performance will be. Table 4 shows that the t-statistic value for the effect of transfer funds on village financial performance is 3.194. This value is greater than the value of $t$ table at a significance level of 5 percent, namely 1.99 , so it can be concluded that the hypothesis is accepted. The $P$ value for the effect of transfer funds on village financial performance is 0.001 smaller than the alpha value of 0.05 . This means that the relationship between transfer funds and village financial performance is significant, so the hypothesis is accepted. The coefficient value of the transfer fund parameter on village financial management accountability is 0.325 with a positive direction. This means that the greater the transfer of funds, the better the village's financial performance. This study has a relationship with the theory of stewardship where there is a relationship between government organizations and the goal to be achieved, namely the welfare of the community. A government organization is an institution that is trusted by the community in carrying out its duties and functions properly in accordance with applicable regulations. By making an accountability report that has been carried out for a period that has been correctly determined in accordance with applicable regulations by streamlining work within the organization that will produce a good financial information report.

The fifth hypothesis states that the larger the other funds will not lead to an increase in the accountability of village financial management. Table 4 shows that the t-statistic value for the effect of other funds on village financial management accountability is 0.378 . This value is smaller than the value of $t$ table at a significance level of 5 percent, namely 1.99 , so it can be concluded that the hypothesis is rejected. The $P$ value for the effect of other funds on village financial management accountability is 0.706 greater than the alpha value of 0.05 . This means that the relationship between other funds and the accountability of village financial management is not significant, so the hypothesis is rejected. The coefficient value of 
the transfer fund parameter on village financial management accountability is 0.024 with a positive direction. This means that other funds do not have an impact on the accountability of village financial management. This research is in line with the stewardship theory of the government as a steward with the function of managing resources and the people as principal owners of resources. There is an agreement that exists between the government (steward) and the people (principal) based on trust, collectively according to the goals of the organization. Public sector organizations have the goal of providing services to the public and being accountable to the public (public). So that it can be applied in the case model of public sector organizations with stewardship theory.

The sixth hypothesis states that larger other funds will not lead to an increase in village financial performance. Table 4 shows that the t-statistic value for the effect of other funds on village financial management accountability is 0.378 . This value is smaller than the value of $t$ table at a significance level of 5 percent, namely 1.99, so it can be concluded that the hypothesis is rejected. The $P$ value for the effect of other funds on village financial management accountability is 0.706 greater than the alpha value of 0.05 . This means that the relationship between other funds and the accountability of village financial management is not significant, so the hypothesis is rejected. The coefficient value of the transfer fund parameter on village financial management accountability is 0.024 with a positive direction. This means that other funds do not have an impact on the accountability of village financial management.

The seventh hypothesis states that the better the financial performance of the village will not lead to an increase in the accountability of village financial management. Table 4 shows that the t-statistic value for the effect of village financial performance on village financial management accountability is 0.701 . This value is smaller than the value of table at a significance level of 5 percent, namely 1.99, so it can be concluded that the hypothesis is rejected. The $P$ value for the influence of village financial performance on village financial management accountability is 0.483 greater than the alpha value of 0.05 . This means that the relationship between village financial performance and village financial management accountability is not significant, so the hypothesis is rejected. The coefficient value of the transfer fund parameter on village financial management accountability is 0.035 with a positive direction. This means that village financial performance does not have an impact on village financial management accountability.

This research is in line with the concept of signaling theory which illustrates that the government will try to give positive signals to the public regarding government performance as a form of government accountability. This positive signal can be in the form of disclosure of financial information that is presented in full through the official local government website. The results of this study are in line with the concept of signaling theory where local governments with good financial performance tend to do Internet Financial Reporting. The results of this study also support stewardship theory. Local governments are more focused on organizational goals, namely providing services to the community in this case is the fulfillment of financial information needs.

\section{CONCLUSION}

One of the performances and responsibilities carried out by the village government in Central Lombok Regency is to increase village original income, the larger the transfer funds received from the central government will reduce the level of village independence, with high village original income can improve village financial management performance and accountability. . From the results of the study, it can be concluded that: village original income has a positive and significant effect on financial performance and accountability of village financial management. Transfer funds have a positive and significant effect on village financial performance. Transfer funds have no significant and significant effect on village financial management accountability. Other funds have no and significant effect on financial performance and accountability of village financial management, while financial performance has no and significant effect on village financial management accountability. 


\section{REFERENCES}

1. Agnes Sawir, 2005. Analisis Kinerja Keuangan Daerah dan Perencanaan Keuangan Perusahaan, PT. Gramedia Pustaka Utama. Jakarta.

2. Amalya,Tuti.Akram dan Pituringsih,E.(2017)."Determinant of Vilage Fnancial Management and Its Implication toward Accountablity (Studyon Village GovernanceinWest Lombok Regency)". International Journal of Research in Advent Technology.Universitas Mataram. Vol.5, No. 12.

3. Ananda, Candra Fajri, 2002. Problems Of The Implementation of Fiscal Decentralization In regional Autonomy: The Case Of Malang Municipality And trenggalek District. Pusat Penelitian Kebijakan Ekonomi, FE-Unbraw.

4. Bambang H. 2002. Analisis Pengaruh Tekanan Keuangan Terhadap Kinerja Keuangan Pemerintah Daerah dalam Menghadapi Otonomi Daerah. Simposium Akuntansi ke V, Semarang.

5. Badan Pusat Statistik Kabupaten Lombok Tengah.

6. Bahl, R. and Linn, J. (1992).Urban Public Finance in Developing Countries. New York: Oxford University Press.

7. Bird, Richard M-Francois Vaillan court, 2000. Fiscal Decenralization in Developing countries, PT.Gramedia Pustaka Utama. Jakarta.

8. Bobby Briando (2017) StudiL iteratur: DesentralisasiFiskalDesa. Jurnal Akuntansi Dan Pendidikan. DOI: 10.25273/Jap.V6i2.1178

9. Donaldson, L., \& Davis, J.H. 1989. CEO governance and shareholder returns: Agency theory or stewardship theory. Paper presented at the annual meeting of the Academy of Management, Washington, DC.

10. Donaldson, L., \& Davis, J. H. 1991. Stewardship theory or agency theory: CEO governance and shareholder returns. Australian Journal of Management, 16: 49-64.

11. Elmi, Bachrul. 2002 Kebijakan Desentralisasi Fiskal Kaitannya Dengan Hutang Luar Negeri Pemerintah Daerah Otonom, Kajian Ekonomi dan keuangan Volume 6, Nomor 4, Desember 2002

12. Erani Yustika, Ahmad, 2008, Desentralisasi Ekonomi di Indonesia Kajian Teoritis dan Realitas Emperis, Bayumedia Pulishing, Malang.

13. Fajri R., Setyowati E., \&Siswidiyanto.(2014). Akuntabilitas Pemerintahan Pada Pengelolaan Alokasi Dana Desa (ADD) (studipada Kantor Desa Ketindan, Keca matan Lawang, Kabupaten Malang).Jurnal Administras Publik (JAP), 3(7), 1099-1104

14. Garfinkel, Irwin, Lee Rainwater. Dan Timothy M. Smeeding. 2005. Welfare State Expenditures and The Redistribution of Well-Being Children, Elders, and Others In Comparative Perspective, New York Maxwell Scholl of Citizenship and Public Affairs Syracuse Univerity.

15. Gungjin, Tisn. 2001. Dinamic Change of Land Use Structure in Hoikow by Remote Sensing, Singapure: 5-9 Nopember.

16. Hanifah,,Suci Indah dan Praptoyo, Sugeng. 2015. Akuntabilitas danTransparans Pertanggungjawaban Anggaran Pendapatan Belanja Desa (APBDes). Jurnall Imu dan Riset Akuntansi. Surabaya: SekolahTinggi Ilmu Ekonomi Indonesia (STIESI A) Surabaya

17. Kaho Josep Riwu, 1997. Prospek Otonomi Daerah Republik Indonesia, Indentifikasi beberapa faktor yang mempengaruhi penyelenggaraannya, Jakarta: Rajawali.

18. Lewis, W. Arthur, 1996. Economic Growth and Sructure, New Delhi: Oxford and IBH.

19. Litvack, Jennie, Ahmad, Jundid, and Bird, Richard. 1998. Decentralization in Developing Country. The Word Bank, Washington, DC.

20. Made Yeni Latrini (2017)Transparansidan Akuntabilitas Pengelolaan Keuangan Dana Desa untuk Mendorong Kemandirian Masyarakat Pedesaan. Jurnal ekonomi kuantitatif terapan. Vol 10 No. 2. DOI: https://doi.org/10.24843/JEKT.2017.v10.i02.p 07.

21. Madyaningtyas, Ratna 2009. Transparansi dan Akuntabilitas Dalam Pengelolaan Alokasi Dana Desa.Yogyakarta,Universitas Gajah Mada'

22. Osborne, David, and Gaebler, T.1992. Reinventing Government: How the Entrepreneurial Spirit is Transforming the Public Sector. New York: Penguins Books. 
23. Panjaitan, Mangasi, 1996. Pengeluaran Pemerintah (APBN) Variabel yang mempengaruhi dan penaruhnya pada pertumbuhan Ekonomi di Indonesia selama PJP I, Tesis, PPS UI, Jakarta

24. Part. John B. 1987.Developent of Spatial Structure and Regioal Economic Growth. Land Economic. Vol 63. No. 2. May 1987. Published; The Board of Regents of The University of Winconsin System.

25. Pemerintah RI,Undang-Undang Republik Indonesia,Nomor 23 Tahun 2014 tentang Pemerintahan Daerah.

26. Perimbangan Keuangan antara Pemerintahan Pusat dan Daerah.

27. Peraturan Menteri Dalam Negeri Republik Indonesia Nomor 113 Tahun 2014 tentang Pengelolaan Keuangan Desa.

28. Purdiyanto,Heri.2017. Determinan Akuntabilitas Pengelolaan Keuangan Desa (Studi Emfiris pada desa di Kabupaten Sumbawa dan Sumbawa Barat).Universitas Mataram

29. Prawirosentono, Suyadi. 2002. Manajemen Sumber Daya Manusia: Kebijakan kinerja Karyawan. Edisi 1.Cetakan Kedelapan. BPFE. Yogyakarta

30. Riduwan. 2004. Statistika untuk Lembaga dan Instansi Pemerintah / Swasta, Alfabeta.

31. Rahmiyati Nekky, 2008. Analisis Pengaruh Kinerja Keuangan Daerah Terhadap Pertumnuhan Ekonomi, Pertumbuhan Investasi, Penyerapan Tenaga Kerja dan Kesejahteraan Rakyat di Provinsi Jawa Timur, Disertasi UNTAG, Surabaya. Tidak dipublikasikan.

32. Rondinelli, Dennis A dan G. (1961).Shabbir Cheema, "Implementing Decentralization Policies; An Introduction", dalam G. Shabbir Cheemadan Dennis A. Rondinelli (Editors), Decentralization and Development Policy Implementation in Developing Countries, Beverly Hills/ London/ New Delhi:Sage Publication.

33. Salusu J, 1998, Pengambilan Keputusan Stratejik, Jakarta: Grasindo

34. Suwondo, L., M. Paramitha, dan D. Tjahjanulin. 2013. Kinerja Aparat Pemerintah Desa Dalam Rangka Otonomi Desa (Studi di DesaGulun, Kecamatan Maospati, Kabupaten Magetan.Jurnal Administrasi Publik, 1 (4), 91-100..

35. Subroto, A. (2009). Accountability of Village Fund Allocation Management (case study in Tlogomulyo Sub-District, Temanggung, Jurnal Akuntansi dan Investasi, 18 (2), 172- 82: Juli 2017182 Regency). Master Theses, Universita sDiponegoro.

36. Sony Yuwono, Dwi Cahyo U. Suhaery Z. Azrafiany A. R, 2008, Memahami APBD dan Permasalahannya, Bayumedia Publishing, Malang.

37. Sidik, Machfud, 2002, 17 April. Format Hubungan Keuangan Pemerintah Pusat dan Daerah yang Mengacu pada Pencapaian Tujuan Nasional. Makalah disampaikan pada seminar Nasional Public Sctor Scorecard, Jakarta

38. Sidik, Machfud, 2001, "Desentralisasi Fiskal: Antara Teori dan kenyataan", makalah yang tidak dipublikasikan, Ditjen Perimbangan Keuangan Pusat dan Daerah, Jakarta

39. Solimun, 2002, Structural Equation Modeling Lisrel dan Amos, Fakultas MIPA Universitas Brawijaya.

40. Solimun, 2004. Structural Equation Modeling, Fakultas MIPA, Universitas Brawijaya.

41. Suparmoko, 2000. Keuangan Negara dalam Teori dan Praktek, BPFE, Yogyakarta.

42. Sutedi Adrian, 2009. Implikasi Hukum Atas Sumber Pembiayaan Daerah Dalam Kerangka Otonomi Daerah,Sinar Grafika, Jakarta.

43. Sasana Hadi, 2005 Analisis Dampak Pelaksanaan Desentralisasi Fiskal Terhadap Pertumbuhan Ekonomi dan Kesenjangan Antar Wilayah, Antar Sektor di Kabupaten/Kota Provinsi Daerah Istimewa Yoyjakarta, Jurnal Bisnis dan Ekonomivol.12 No.2 september 2005 FE Universitas Gajah Mada, Yoyjakarta

44. Shah, Anwar dan Zia Qureshi, 1994 Intergovernmental Fiscal Relations in Indonesia, World Bank Discussion Paper No. 239, The World Bank, Washington DC.

45. Tarigan, Robinson., 2005. Perencanaan Pembanguna Wilayah, Edisi Revisi, Bumi Aksara. Jakarta

46. Thomas. 2013. PengelolaanAlokasi Dana Desa Dalam Upaya Meningkatkan Pembangunan Di Desa Sebawang Kecamatan Sesayap KabupatenTanaTuding. Journal Pemerintahan Integratif, 1(1), 51-64. 